\title{
NURCHOLIS MADJID'S CONCEPT OF EDUCATION (AN ANALYSIS OF THE CONCEPT OF EDUCATION CURRICULUM DEVELOPMENT IN PESANTREN)
}

\author{
M. Fazlurrahman Hadi \\ safanahalfariziyah@gmail.com
}

\begin{abstract}
The Islamic boarding (Pesantren) education curriculum is a tool to achieve the objectives of Islamic Education. Decreasing of students' morallity, equal learning opportunities, low internal efficiency of the education system, institutional status, management of education that is not in line with national development, and unprofessional human resources. The problem faced by pesantren in this era is the narrowing of the curriculum which study of the sciences only grammatically such as: nahwu-sharaf, fiqh, aqa'id, tasawuf, tafsir, hadith, and Arabic. In this context, education curriculum in Pesantren needs to be reformulated including its vision and objectives as well as develop the curriculum. The application of the curriculum in Pesantren needs to be checked and balanced including the balance of classical Islamic repertoire, Islamic knowledge, and general knowledge. Santri (students in Islamic boarding school) can study these sciences not only grammatically, but how to master the sciences verbally or text. So, products (santri) are not only as consumers but producers. Thus, this article is intended to explore Nurcholis Madjid's concept of the education curriculum in pesantren. Meanwhile, the reason why this thesis is only focused on studying the concept of a e certain figure is because Nurcholis Madjid is a prominent Indonesian Islamic intellectualist who is credible to investigate the reality of the world of education in pesantren.
\end{abstract}

Keywords: Curriculum and Education, Pesantren (Islamic Boarding Schools)

\section{A. INTRODUCTION}

Pesantren is an educational system which grows and create based on Indonesian culture (indigenous). This institution is seen as a basic model for developing a new educational concept in Indonesia. Potentially, these characteristics become considerable opportunities used as a foundation to react on globalization and other problems faced by pesantren, in particular, and the wider community, in general. ${ }^{1}$

Pesantren, with the theology it holds up to now, is challenged to react on globalization critically and wisely. Pesantren must be able to find truly

\footnotetext{
${ }^{1}$ Nurcholish Madjid, Modernisasi Pesantren, (Bandung: Ciputat Press), 9.
} 
enlightening solutions. So, on the one hand, it can foster students with broad insights not to giddy in facing modernity and do not lose their identity. While, on the other hand, it can lead people to be aware of the problem faced and able to overcome it with full independence and civilization.

As the oldest Islamic educational institution in Indonesia, pesantren is the basic of hope. According to Nurcholis Madjid, "the motto of realizing civil society will be realized if pesantren institutions respond to the development of the modern world". ${ }^{2}$

One important component of formal educational institutions used as a reference for determining the content of teaching, directing the process of educational mechanisms, measuring the success and quality of educational outcomes, is the curriculum. ${ }^{3}$ However, the curriculum is often unable to keep up with the pace of the development of society. Therefore, the development and improvement of the curriculum must always be carried out continuously.

In pesantren, there are two models of educational systems, the modern pesantren education system and the traditional pesantren education system. Actually, this is occurred due to the expansion of modern education of Dutch colonizers concept at that time. Later on, some pesantrens which wants to keep their continuity respond it by "refusing while imitating". ${ }^{4}$

The model of the modern pesantren educational system is an institutional system managed in a modern technique in terms of administration, teaching system, and curriculum. In this modern educational system, the progress of pesantren are not only seen from the figure of Kiai and Santri, but also seen from the regularity of administration (management) aspects. For example, it is seen in the data of students' enrollment and the report of the education progress of all students.

Furthermore, the curriculum or subject learned consists of various subjects both religious and general subjects. Religious studies are not limited to studying classical books and one school, but various works of classical and contemporary Muslim intellectuals and do not limit on a certain school. Modern pesantren also organizes reguler educational institutions such as junior high school, high school, or

\footnotetext{
${ }^{2}$ Nurcholis Madjid, Bilik- Bilik Pesantren Sebuah Potret Perjalanan, (Jakarta: Paramadina, 1992), 95-96.

${ }^{3}$ Nasution, Kurikulum dan Pengajaran (Jakarta: Bumi Aksara, 1995), 13.

${ }^{4}$ Nurcholish Madjid, Bilik-bilik, 14
} 
college. ${ }^{5}$ As an example of a well-known modern pesantren is the Gontor boarding school and Al-Amien Prenduan Madura.

While the model of traditional pesantren educational system is a pesantren institution that maintains the teaching of classical Islamic books as the core of education. ${ }^{6}$ The practice of traditional Islamic education is still strongly tied to the schools of thought of the scholars of Islamic jurisprudence (theorists of Islamic law), hadith, tafsir (translation and interpretation), tauhid (Islamic theology) and Sufism who live between the seventh to thirteenth centuries. ${ }^{7}$

Viewed from the aspect of curriculum, traditional pesantren education focuses on religious material, nahwu sharaf (grammar) and general knowledge. The religious curriculum is written subject and contains elements of Arabic language, where the material studies focus on fiqh, aqaid, and tashawuf. Fiqh (Jurisprudence) is the most important aspect, then followed by Aqeeda (the creed). While Sufism is only a recommendation and is the privilege of certain people.

Moving on from his concept, Nurcholish Madjid explains about the objective conditions of pesantren in Indonesia. He argues that, historically, pesantren does not only contain Islamic values, but also the meaning of Indonesian authenticity. The forerunner of pesantren actually exists in the Hindu-Buddhist era, and Islam is just continued, preserved, and Islamized it. ${ }^{8}$ As in the research of A. steenbrink that terminologically the educational teaching system of pesantren in Indonesia originated from India before the spread of Islam in Indonesia. The system has been used generally for teaching Hindu education in Java.

In these objective conditions, in order to make pesantren more ideal, Nurcholis offers the need for reconstruction of the objectives of pesantren including reformation and renewal of pesantren management. ${ }^{9}$ In this case, the lack of capability of pesantren in responding and following the development of the era lies in the weakness of the vision and the objectives pesantren educational

\footnotetext{
${ }^{5}$ Wahyoetomo, Perguruan Tinggi Pesantren: Pendidikan Alternatif Masa Depan (Jakarta: Gema Insani Press, 1997), 87.

${ }^{6}$ Ibid., 83.

${ }^{7}$ Zamaksyari Dhofier, Tradisi Pesantren: Studi tentang Pandangan Hidup Kiyai, (Jakarta: LP3ES, 1994), 1.

${ }^{8}$ Yasmadi, Modernisasi pesantren, Kritik Nurcholis Madjid terhadap Pendidikan Islam Tradisional (Jakarta: Ciputat Press 2002), 62

${ }^{9}$ Ibid., 18
} 
system. ${ }^{10}$ Basically, the goal of pesantren is to create and develop Muslim personalities that are beneficial to religion, society and the state, and to form human beings who have a high awareness that Islamic science actually covers a very broad scope including God, humans and nature as well as mathematics, astronomy and mathematical earth science as proven by the number of modern (western) terms in these fields coming from Muslim scientists. ${ }^{11}$ The ultimate goal is faith, knowledge and charity.

According to the concept presented by Nurcholis Madjid in his works, he argues that the education curriculum in pesantren must be able to provide a twodimensional development direction for students, namely the divinity dimension and the human dimension. If it is classified, the concept of developing a pesantren education curriculum, according to Nurcholis Madjid, is a form of progressive education and spirituality. This is proven by paying attention to the two educational orientations above and the principles of Nurcholis Madjid's concept which often emphasize openness, flexibility, critical thinking, democracy, desacralization or secularization, or the ideals of a tolerant and pluralistic civil society. All of these modalities are then realized as an agenda for the renewal of Islamic education through a set of methodologies that some of them have identified as methods of rational thinking, problem solving, experimentation, contemplation, discussion, and mastery of foreign languages.

\section{B. RESEARCH METHODOLOGY}

This research is conducted through library research. This research is conducted based on library data without an empirical test. In this context, literature study is a study of texts whose entire substance is processed philosophically and theoretically. ${ }^{12}$ Because this research is entirely based on literature review or literature and the approach used is library research, this research specifically aims to collect data or information using data provided in library, articles, newspapers,

\footnotetext{
${ }^{10}$ Mujamil Qomar, Pesantren: dari Transformasi Metodologi Menuju Demokratisasi Institusi, (Jakarta: Erlangga, 2005), 4.

${ }^{11}$ Nurcholis Madjid, Islam, doktrin dan Peradaban, (Jakarta: Paramadina) 1992, xii

${ }^{12}$ Neong Muhadjir, Metode Kualitatif, (Yogyakarta: Rake Saranin, 1996), 158-159
} 
and various records in various electronic and printed media. ${ }^{13}$ While the source of the data are:

a. Primary Data Sources

The primary data sources are data taken from the original work on the figure discussed in this research. The sources used in this research are:

1) Nurcholish Madjid. Islam Universal, (Yogyakarta: Pustaka Pelajar, 2007)

2) Nurcholish Madjid, Islam Kemodernan Dan Keindonesiaan, (Bandung: Mizan, 1993)

3) Nurcholish Madjid, Tradisi Islam Peran Dan Fungsinya Dalam Pembangunan Indonesia, (Jakarta: paramadina, 1997)

4) Nurcholish Madjid, Bilik-Bilik Pesantren, sebuah potret perjalanan, (Jakarta: Paramadina, 1992)

5) Nurcholish Madjid, Merumuskan Kembali Tujuan Pendidikan, (Jakarta: P3M, 1985)

6) Yasmadi, Modernisasi pesantren, Kritik Nurcholis Madjid terhadap Pendidikan Islam Tradisional (Jakarta: Ciputat Press 2002)

b. Secondary Data Sources

1) Mardialis, Metode Penelitian: Suatu Pendekatan Proposal, (Jakarta: Bumi Aksara, 1995)

2) Dr. H.M. Khusnuridlo, Manajemen Pondok Pesantren dalam Perspektif Global, (Yogyakarta: LaksBang PRESSindo, 2006)

3) Abd. A'la, Pembaharuan Pesantren, (Yogyakarta: Pustaka Pesantren, 2006)

4) Mustofa Harun, Khazah Intelektual Pesantren, (Jakarta: Maloho Jaya Abadi, 2009)

5) And other supported resources.

Data collection methods used in this qualitative research is

${ }^{13}$ Mardialis, Metode Penelitian: Suatu Pendekatan Proposal, (Jakarta: Bumi Aksara, 1995), 28. 
documentary methods. ${ }^{14}$ The data are variables in form of notes, transcripts of books, newspapers, magazines, inscriptions, notes of meetings, agenda and so on. ${ }^{15}$

The collected data is analyzed using the following methods: a) Content analysis method. Content analysis is a scientific analysis of the content message of a communication. ${ }^{16}$ Content analysis is a research technique to make inferences (the process of drawing conclusions based on previous considerations or general considerations; conclusions) that can be replicated, and validate the data by considering the context. ${ }^{17}$ b) Historical Analysis Method, by using this method the author intends to illustrate the biography of Nurcholish Madjid, both related to the historical environment and the influences experienced including educational history, background of thought, and works. ${ }^{18}$ c) Descriptive analysis method, which is a method that describes regularly all conceptions of figures that are discussed in a complete and details. ${ }^{19}$

\section{RESEARCH RESULTS AND DISCUSSION}

Islamic education institutions (Pesantren) as an alternative institution is expected to be able to prepare qualified society characterized by a spirit of fairness, egalitarian, cosmopolitan, democratic, and open-minded, both in religious science and modern sciences. Responding on the reality of education today, Nurcholis Madjid tries to modernize Islamic education (Pesantren). This effort is intended to find an ideal format of education as an alternative educational system for Indonesian in the future. The advantages and benefits of past educational institutions are used as a reference framework to reconstruct the concept of education. While the old system that is less relevant will be abandoned and discarded.

\footnotetext{
${ }^{14}$ Burhan Bungun, Analisi Data Penelitian Kualitatif, (Jakarta: Raja Grafindo Persada, 2003), 68

${ }^{15}$ Sanapiah Faisal, Metode Penelitian Pendidikan, (Surabaya: Usaha Nasional, 1993), 133

${ }^{16}$ Noeng Muhadjir, Metode Kualitatif, 159

${ }^{17}$ Burhan Bungun, Analisi Data Penelitian Kualitatif, 172-173

${ }^{18}$ Anton Bakker, Drs. Ahmad Charis Zubair, Metodologi Penelitian Filsafat, (Yogyakarta: Kanisius, 1990), 70

${ }^{19}$ Sudarto, Metode Penelitian Filsafat, (Jakarta: Raja Grafindo Prasada, 1997), 100
} 
Thousands of pesantren in Indonesia have succeeded in fulfilling part of the educational gap in Indonesia. Educational institutions have their own historical treasures because they exists long time before the Proclamation of Independence on August 17, 1945. Because of that severe, each pesantren has its own unique characteristics, with its advantages and disadvantages. ${ }^{20}$ According to the history of Indonesian Islamic education, pesantren as a traditional Islamic education system plays an important role in shaping the quality of Indonesian human resources. Based on Nurcholish madjid's concept, pesantren can be used as an alternative to the existing system. He states that the educational system at that time was still very employee oriented so it become one of the problems of educational system in Indonesia. $^{21}$

Although the institution has followed the modern era (education), there are still weaknesses in the view of Nurcholish Madjid. Nurcholish Madjid, one of the egalitarian students with openness, cosmopolitan, and democratic, conducts a review of the condition of the pesantren world. The study is aimed to give strong criticism towards the world of pesantren. In detail, Nurcholish Madjid's review involves: the formulation of pesantren goals, the narrowing of curriculum orientation, and the scoring system in pesantren.

\section{Re-formulate the Objectives of Educational System in Pesantren}

Education is a process so the measurement of the educational process is how the goals of education can be achieved. The aim to be achieved by education is essentially an embodiment of ideal values formed in humans. The formation of these values can be applied to the planning of the education curriculum as the basic foundation for the implementation of the operation itself.

Factors that makes educational system in pesantren inable to follow and take a charge in the development era is the weakness of the vision and the objectives of pesantren. Relatively, just few pesantren are able to consciously formulate educational objectives and put them in work plans or programs.

\footnotetext{
${ }^{20}$ Nurcholish madjid, Islam Kerakyatan dan keindonesiaan, cet ke-3, (Bandung: Mizan, 1996), 222-223

${ }_{21}$ Nurcholish Madjid, "Merumuskan Kembali Tujuan Pendidikan Pesantren" dalam DawamRahardjo(ed), Pergulatan Dunia Pesantren, Membangun dari Bawah, (Jakarta: P3M, 1985), 3.
} 
According to Nurcholis Madjid, the tendency is due to: "There is an improvisation process created by the Kyai or together with his colleague intuitively adjusted to the development of the pesantren. In fact, basically pesantren is the reflection of personality of its educators. So it is not surprising if there is an assumption that almost all pesantren are the result of personal or individual business (individual enterprise). It seems that Nurcholish Madjid sees the obscurity of direction and target that the pesantren wants to be achieved. Moreover, Kyai as a strong factor plays central role in pesantren (Islamic boarding school). Kyai as the most essential element in pesantren naturally has a great impact on the growth pesantren. This depends solely on its personal abilities of the Kyai.

In line with this, Komarudin Hidayat says that Pesantren usually run its system not based on development strategies and theories established by the government, but base on appreciation and understanding of the Kyai which is then reflected and actualized as pious deeds. ${ }^{22}$ Therefore, by normative and theoretical approach in observing the pesantren based on the western social sciences, it is always inaccessible and unable to go to the deeper reality of the pesantren world.

In this contexts, Nurcholish Madjid exemplified a Kyai who unable to read latin letters/literacy has a greater tendency to refuse and inhibit the inclusion of literacy into the pesantren curriculum. So it is not surprising that pesantren only produces pesantren products that are considered not ready to "melt" and participate in modern life. In other words, pesantren is only able to bring up santri with limited abilities. ${ }^{23}$ Besides, the method used by Kyai in teaching and learning process has ignored the cognitive aspects. This has a negative impact on the out put of the pesantren.

Indeed, it is realized that education in pesantren not only focuses on cognitive aspects such as modern educational institutions now, but precisely on the affective and psychomotor aspects. It is clear how students want and are able to realize the values of Islamic teachings and internalize themselves and realize

\footnotetext{
${ }^{22}$ Dawam Raharjo. Pergulatan Dunia Pesantren. (Jakarta: LP3ES, 1985), 74

${ }^{23}$ Yasmadi. Modernisasi Pesantren, 74
} 
in their behavior and life. If the direction and purpose of education is considered a point of weakness and inertia in the world of pesantren. So, Nurcholis Madjid says that the thing that must be addressed in pesantren is how to balance between cognitive, affective and psychomotor goals.

\section{Curriculum Orientation Narrowing}

Curriculum is one of the instruments of an educational institution, including pesantren. To get an idea of the meaning of curriculum, the first definition of curriculum will be mentioned. According to Iskandar Wiryokusumo, curriculum is an education program provided by schools for students. ${ }^{24}$ Meanwhile, according to S.Nasution, curriculum is a plan of preparation to facilitate teaching-learning process under the guidance and responsibility of school or educational institution and its teaching staff. ${ }^{25}$

Nurcholish Madjid's point of view of the pesantren education curriculum shows that religious studies are still dominant in the pesantren environment. Moreover, lessons are more specifically presented in Arabic. The lessons are Fiqh, nahwu, aqa'id sharaf, while tasawuf and religiosity which is the core of religious curriculum tends to be ignored. ${ }^{26}$ In term of lesson, Nurcholish Madjid says that: The words "religion" are more focused on the formal aspects and knowledge. While "religiousness" is more about spirit and sense of religiosity. This "religiousness" topic is not discussed in dept. Whereas, this is precisely functions more in modern society rather than fiqh, the knowledge of kalam, Nahwu-sharaf (linguistics), and the Arabic language. On the other hand, general knowledge seems to be more half-carried out, so the ability of santri is usually very limited and lacks recognition from the general public. ${ }^{27}$

In detail, Nurcholish Madjid says that the narrowing orientation of pesantren education curriculum involves nahwu-sharaf, fiqh, aqa'id, tasawuf, tafsir, hadith, and Arabic. The study of those lessons is not only grammatically,

\footnotetext{
${ }^{24}$ Iskandar Wiryokusumo dan Usman Mulyadi, Dasar-dasar Pengembangan Kurikulum (Jakarta: Bina Aksara, 1988), 6.

${ }^{25}$ Nasution, kurikulum, (Bandung: Tarate, 1964), 5

${ }^{26}$ Nurcholish Madjid, Bilik-Bilik Pesantren, 100-101

27 Yasmadi. Modernisasi Pesantren, 78.
} 
but how to master the lessons verbally or textually so the product (santri) is not only as a consumer but also a producer. ${ }^{28}$ In responding to the pesantren curriculum, it seems that Nurcholish Madjid emphasizes that the implementation of the curriculum in pesantren has checked and balanced. The balance is between classical Islamic repertoire, Islamic knowledge, and general knowledge. $^{29}$

Having analize ideas from several Islamic experts, Nurcholish Madjid, a Muslim scholar who reveals many treasures of classical Islamic wealth, argues that in the world of pesantren efforts should be made to eliminate the dualism of education, namely an institution focused on "modern sciences" and an institution focused on "traditional sciences". This is apart from efforts to eliminate scientific dichotomies today. It is because the scientific dichotomy has a great impact on the dynamics of Muslims themselves.

During the golden era of Islam, there is hardly any scientific dichotomy between "general sciences" and "Islamic sciences". The development of science goes so fast, including religion, language, history, algebra, physics, medicine, and others. The scientists, such as Ibnu Sina, Ikhwan Al-Safa, and others, realize that human perfection would be realized by harmonizing between "general sciences" and "Islamic sciences", as an inseparable part in scientific component in Islam.

Nurcholish Madjid's concept is focused on efforts to insert the "general" curriculum, applied in general education, into Islamic education which has its own curriculum. So, there will be a combination of two forms of scientific elements on a complete scale. In this context, Nurcholish Madjid hopes that by combining two scientific elements, human beings will have intellectual property both Islamic insights and modern science insights. This is the target and objective of Islamic education which is reflected in the curriculum estblishment.

\section{B. An Analysis of Education Curriculum Development in Pesantren Based on}

\footnotetext{
${ }^{28}$ Nurcholish Madjid, Bilik-Bilik Pesantren, 11.

${ }^{29}$ Yasmadi, Modernisasi Pesantren., 90.
} 


\section{Nurcholish Madjid's Concept}

"If pesantren is expected to respond to these challenges, then the focus is regarding to two universal aspects, science and technology". 30

In relation to the text above, if pesantren wants to be able to play a role in the community, there must be new breakthroughs in response to challenges in society. Regarding to the curriculum in pesantren, Nurcholis Madjid states that there are three models of educational renewal approaches as follows: ${ }^{31}$

1) Islamization of science

The Islamization of science in this context means to Islamize modern secular education. This education is done by accepting modern secular education and then trying to "Islamize" it by fill it with certain concepts of Islam. This aims to shape the paradigm of Islamic values in various disciplines, and to use Islamic perspectives to change the content of scientific studies orientation.

2) Simplicity of the Syllabus

Steps are done in simplifying traditional syllabus. These steps are directed entirely in the framework of traditional education. This update emphasize on the fields of language, Arabic literature, and principles of Qur'anic interpretation.

3) Integration of science

This is done to unite the branches of classical science and modern science. According to Nurcholish Madjid, good education can creat a liberal and critical man where he can become an independent person. ${ }^{32}$ According to him, the system and institutions of Islamic Education will be weaker, unrecognized, or even disappeared if the educational system only promotes moral aspects

\footnotetext{
${ }^{30}$ Nurcholis Madjid, Bilik-bilik Pesantren Sebuah: Potret Perjalanan (Jakarta: PT. Dian Rakyat, t.th.), 96. "itu"maksudnya perwujudan proses modernisasi. Modernisasi bukan berarti westernisasi yang sering diartikan barat yang Kristen. Lebih lanjut baca Nurcholish Madjid, Tradisi IslamPeran dan fungsinya dalam Pembangunan di indonesia (Jakarta: Paramadina, 2008),75.

${ }^{31}$ Muhaimin dan Abdul Mujib, Pemikiran Pendidikan Islam: Kajian Filosofis dan Kerangka Dasar Operasionalisasinya (Bandung: Trigenda Karya, 1993), 315.

${ }^{32}$ Nurcholish Madjid, Islam Kerakyatan dan keindonesian: Pikiran-pikiran Madjid,,Muda", (Bandung: Mizan, 1993), 330-331.
} 
without developing science and technology. ${ }^{33}$

Furthermore, Nurcholish Madjid states that by considering efficiency and limited costs and other factors, it is necessary to set a priority scale outlined in the work plan both for short term and long term. It is because in the current condition pesantren is faced a difficult era, such as Kyai in cities who have increased in their status believe more in sending their children to public schools than pesantren. ${ }^{34}$

According to Nurcholish madjid's concept, that in facing increasingly complex era, pesantren is required to make changes in the curriculum. To respond on the renewal of curriculum, there are two types of steps that must be considered,

a) Intellectual Development, b) Thought Paradigm.

1) Intellectual Development

Humans thought is an integral part of his life history. The same is true of one's thoughts that cannot be separated from the situation and conditions that raised them. This seems to be inseparable from Nurcholis Madjid who lives and develops in the socio-political situation that is looking at her.

In short, religious intelectual development of Nurcholish Madjid is divided into two periods. The first period is in the 80 s and the second period is in the 90s. In the first period, the themes discussed by Nurcholish Madjid are about modernization and secularization. While in the second period, the themes are Islamic universalism and pluralism.

2) Thought Paradigm

To understand the worldview or the philosophical framework of Nurcholish Madjid's concept is to open his views on the Qur'an in terms of inspiration, nature, and purpose. This is due to the characteristics of Nurcholish Madjid's view of the Qur'an, and the totality of his thoughts which are formed and directed by the philosophy.

a) Ideas for Islamic Education Renewal

\footnotetext{
${ }^{33}$ Ibid., 228-229

${ }^{34}$ Nurcholis Madjid, Bilik-bilik Pesantren Sebuah: Potret Perjalanan, (Jakarta: PT. Dian Rakyat, t.th.), 108.
} 
The idea of reforming Islamic education in Indonesia inspires from the traditional and modern educational system. The traditional Islamic education system have a conservative educational content. According to Nurcholish Madjid, this culture does not give freedom of thought which results in personal lack of ability to balance and control global life and even respond it.

Nurcholish Madjid experiences a shift of paradigm of thinking after the first visitation to the land of Uncle Sam (America). The conception of Nurcholish Madjid is modern and radical monotheism. So, it brings up ideas about secularization and Islamic inclusivism and universalism.

1. Nurcholish version of secularization is to put the values of world in its place and release the Muslims from the tendency of the hereafter.

2. The notion of inclusivism and Islamic universalism in Nurcholish's opinion is that Islam is not synonymous with ideology.

3. While modern ideas articulated through jargon "modernization is rationalization, not westernization."

b) The Concept of Education Based on Nurcholis Madjid Perspectives

In the process of further development of Islamic thought, the heavyminded thinking orientation (sufi) gets challenges. Moreover, after the rise of Muslims in Indonesia, the existence of modern ships with steam engines ease more people going to the holy land (mecca), so communication with people from purer Islamic thought and ideology towards the Shari'a is getting stronger. ${ }^{35}$ This raises a wave of thought that is leaning to shari'ah or fiqh, and speaks Arabic, then institutionalizes in education system and curriculum in the the pesantren. ${ }^{36}$

According to Nurcholish Madjid, the ideal system of Islamic Education is the education system that can shape the liberal mindset such as

\footnotetext{
${ }^{35}$ Nurcholish Madjid, Tradisi Islam Peran dan Fungsi dalam Pembangunan di Indonesia (Jakarta: Paramadina, 2008), 8.

${ }^{36}$ Nurcholish Madjid, Islam Agama Kemanusian: Membangun Tradisi dan Visi Baru Islam Indonesia (Jakarta: Paramadina, 1995), 32.
} 
intellectualism which can lead humans to two very closely related tendencies, break away from traditional values and look for future-oriented values that based on the Qur'an and as-Sunnah. Having the purpose of da'wah which is to spread religious morality and the development of science and technology. ${ }^{37}$ In other words, his concept of education is a concept which has a traditional and modern role.

The first role is the concept of traditional education aimed to: 1) as the transmission and transformation of Islamic sciences 2) Maintenance of Islamic traditions and 3) as reproduction of scholars'. While the second role is the concept of modern education which has universal goals s follows: 1) as a community service center such as health and environmental counseling with a religious approach, the center of developing appropriate technology for the community. 2)create professional human resources, and 3) socioeconomic empowerment. The concept of education is directed at solving problems faced by society and having a universal worldview based on the Qur'an and Hadith.

From the concept of education initiated by Nurcholish Madjid, the development of the education curriculum in pesantren in the prespective of Nurcholish Madjid. The renewal is in the form of secularization, intellectual freedom, and an open-minded to new ideas.

\section{CONCLUSION}

The pesantren education curriculum is the material of Islamic education in pesantren in the form of activities, knowledge, and experiences that are deliberately and systematically given to students in order to achieve the objectives of Islamic Education. Education curriculum in pesantren is a tool to achieve the objectives of Islamic Education. The scope of education material in pesantren is the Qur'an and Hadith, Faith, morality, Fiqh/ worship and history.

\footnotetext{
37 Junaidi Idrus, Rekonstruksi Pemikiran Nurcholish Madjid, Membangun Visi dan Misi Baru Islam Indonesia, (Jogjakarta: Logung Pustaka, 2004), 54, mengatakan Al-Qur'an dan Hadis harus di tafsirkan secara kreatif dan kritis dan bertanggung jawab serta dipahami secara keseluruhan dengan menggunakan metode filosofis sehingga nilai-nilai universal yang dikandungnya menjadi landasan yang kukuh bagi segala tindakan umat, dan dapat disesuaikan dengan kehidupan konkret.
} 
In other words, the scope of education in pesantren is the harmony and balance of human relations with God, self, fellow human beings, other creatures, and the environment.

In terms of developing the curriculum, there are several fundamental reasons why educational innovation seems urgent to be done such as: students' characters and morals decrease, equal learning opportunities, low internal efficiency of educational system, institutional status, management of education that is not in line with national development, and unprofessional human sources.

Recognizing these problems, the innovation of the education curriculum as part of efforts in improving the quality of education must be carried out comprehensively, especially regarding to the quality of education and its relevance to the needs of the community.

In responding to the pesantren curriculum, it seems that Nurcholish Madjid emphasized on the implementation of the curriculum in pesantren with check and balance. The balance is between classical Islamic repertoire, Islamic knowledge, and general knowledge. Based on Nurcholish Madjid point of view, education system in pesantren needs to be reformulated its vision and objectives and put it in the stages of the work plan or program. Nurcholish Madjid says that orientation narrowing of the education curriculum in pesantren involves nahwusharaf, fiqh, aqa'id, tasawuf, tafsir, hadith, and Arabic. Where the study of sciences is not only grammatically, but how to master the sciences verbally or textually so the product (Santri) is not only as a consumer but a producer.

Furthermore, in terms of terminology, he explains that the ideal Islamic education system is an education system which can shape a liberal mindset into intellectualism that can lead people to two tendencies with very closely related, namely to break away from traditional values and seek values that are oriented into the future based on the Qur'an and as-Sunnah. The purpose of $d a^{\prime} w a h$ is to spread religious morality and the development of science and technology. In other words, his educational concept is a concept that has a traditional and modern role. From the concept of education initiated by Nurcholish Madjid, the development of the pesantren curriculum based on the prespective of Nurcholish Madjid is raised. The renewal is in the form of secularization, intellectual 
freedom and an open attitude of new ideas.

\section{E. LIST OF REFERENCES}

Madjid, Nurcholis. 1992. Bilik- Bilik Pesantren Sebuah Potret Perjalanan. Jakarta: Paramadina.

Mastuhu. 1999. Memberdayakan Sistem Pendidikan Islam. Jakarta: Logos Wacana Ilmu.

Nurwahid, Hidayat. 2006. Sekolah Islam Terpadu: Konsep dan Aplikasinya. Jakarta: Syaami Cipta Media.

Nasution. 1995. Kurikulum dan Pengajaran. Jakarta: Bumi Aksara.

Wahyoetomo. 1997. Perguruan Tinggi Pesantren: Pendidikan Alternatif Masa Depan. Jakarta: Gema Insani Press.

Dhofier, Zamaksyari.1999. Tradisi Pesantren: Studi tentang Pandangan Hidup Kiyai. Jakarta: LP3ES.

Yasmadi. 2002. Modernisasi pesantren, Kritik Nurcholis Madjid terhadap Pendidikan Islam Tradisional. Jakarta: Ciputat Press.

Qomar, Mujamil. 2005. Pesantren: dari Transformasi Metodologi Menuju Demokratisasi Institusi. Jakarta: Erlangga.

Madjid, Nurcholis. 1992. Islam, doktrin dan peradaban, Jakarta: Paramadina.

Nata, Abuddin. 2005. Tokoh-tokoh Pembaruan Pendidikan Islam Indonesia. Jakarta: Raja Grafindo Persada.

Madjid, Nurcholis. 1993. Islam kerakyatan dan keindonesiaan. Bandung: Mizan, 1993.

M. Elchols, John dan Shadily, Hasan. 1996. Kamus Inggris-Indonesia. Jakarta: Gramedia Pustaka Utama.

Partanto, A. Pius. 1994. Kamus Ilmiah Popular. Surabaya; Arkola.

Hamalik, Oemar. 1994. Kurikulum Dan Pembelajaran. Bandung: Bumi Aksara.

Kurinasih, Imas dan Sani, Berlin. 2014. Implementasi kurikulum 2013 Konsep dan Penerapan. Surabaya: Kata Pena.

Tim Penyusun Kamus P.P.P.B. Dep. Dik. Bud.1999. Kamus Besar Bahasa Indonesia, edisi Kedua, Jakarta, balai Pustaka. 
Indrakusuma, Amir Daien.1975. Pengantar Ilmu Pedidikan Islam. Bandung: AlMa'arif.

Prasodjo, Sudjono. 1982. Profil Pesantren. Jakarta: LP3S.

Madjid, Nurcholish. 2003. Islam Agama Kemanusiaan; Membangun Tradisi dan Visi Baru Islam Indonesia. Jakarta: Paramadina.

Muhadjir, Neong. 1996. Metode Kualitatif. Yogyakarta: Rake Saranin.

Mardialis, 1995. Metode Penelitian: Suatu Pendekatan Proposal. Jakarta: Bumi Aksara.

Bungun, Burhan. 2003. Analisi Data Penelitian Kualitatif. Jakarta: Raja Grafindo Persada.

Faisal, Sanapiah.1993. Metode Penelitian Pendidikan. Surabaya: Usaha Nasional. Arikunto, Suharsimi.1996. Prosedur Penelitian. Jakarta: Rineka Cipta.

Bakker, Anton dan Charis Zubair Ahmad.1990. Metodologi Penelitian Filsafat. Yogyakarta: Kanisius

Sudarto. 1997. Metode Penelitian Filsafat. Jakarta: Raja Grafindo Prasada.

Masyhud, Sulthon dan Khusnurdhilo.2004. Manajemen Pondok Pesantren. Jakarta:

Diva Pustaka.

Menteri Pendidikan Nasional. 2003. Undang-Undang RI No 20 Tahun 2003. Tentang SISDIKNAS. Jakarta: Sinar Grafika.

Arifin. 1995. Kafita Selekta Pendidikan islam (Islam dan Umum). Jakarta: Bumi Aksara.

Nata, Abuddin. 2001. Filsafat Pendidikan Islam. Jakarta: Logos wacana Ilmu.

Sulthon, Khusnurdhilo. 2006. Manajemen Pondok Pesantren. Jakarta: Diva Pustaka.

Muchtar, H. Isfandi. 1995. Kurikulum sebagai Acuan Tingkah Laku Belajar. Semarang Fakultas Tarbiyah IAIN Walisongo.

Subandiyah. Pengembangan dan Inovasi Kurikulum. Bandung: Citra Aditya Bakti.

Wahid, Abdurrahman. 2009. Kurikulum Pesantren dan Penyediaan Lapangan Kerja

“Dalam Bunga Rampai Pesantren”. Jakarta: CV Dharma Bhakti, tt)

Maunah, Binti. 2009. Tradisi Intelektual Santri. Yoyakarta: Teras.

Ditpekapontren Ditjen kelembagaan islam. 2003. Pola Pembelajaran di Pesantren. Jakarta: Depag RI 
Madjid, Nurcholis. 1992. Islam Doktrin dan peradaban, Sebuah Telaah Kritis Masalah Keimanan, Kemanusian Dan Kemodernan. Jakarta: Paramadina, 1992.

Ditpekapontren Ditjen Kelembagaan Agama Islam. 2003. Pola Pengembangan Pondok Pesantren. Jakarta: Depag RI.

Depag RI. 1999. Al-Qur'an dan Terjemahannya. Semarang: PT. Toha Putra.

Mundhier Suparta dan Amin Haidar. 2003. Manajemen Pondok Pesantren. Jakarta: Diva Pustaka.

Dhofier, Zamakhsyari. 2011. Tradisi Pesantren. Jakarta: LP3ES.

Azizi, Qodri A.2000. Islam dan Permasalahan Sosial. Yogyakarta: LKIS.

Barton, Greg. 1999. Gagasan Islam Liberal Indonesia. Jakarta: Paramadina.

Saiman, Iqbal Abdurrauf. 1988. Polemik Reaktulisasi Ajaran Islam. Jakarta: Pustaka Panjimas.

Sufyanto. 2001. Masyarakat Tamaddun: Kritik Hermeneutik Masyarakat Madani Nurcholish Madjid. Yogyakarta: LP2IF dan Pstaka Pelajar Offset.

Madjid, Nurcholish. 2004. Biografi dalam Surat-surat Politik Nurcholish MadjidMuhamad Roem. Jakarta: Djambatan.

Madjid, Nurcholish. 1985. Merumuskan Kembali Tujuan Pendidikan Pesantren dalam DawamRahardjo(ed), Pergulatan Dunia Pesantren, Membangun dari Bawah. Jakarta: P3M.

Mas'ud, Abdurrahman. 2004. Intelektual Pesantren, Perhelatan Agama dan Tradisi. Jakarta: LKiS.

Iskandar Wiryokusumo dan Usman Mulyadi. 1988. Dasar-dasar Pengembangan Kurikulum. Jakarta: Bina Aksara.

Azra, Azyumardi. 2011. Pendidikan Islam, Tradisi dan Modernisasi Menuju Milenium Baru. Jakarta: Kalimah.

Azra, Azyumardi. 1999. Esei-Esei Intelektual Muslim dan Pendidikan Islam. Jakarta: Logos Wacana Ilmu.

Madjid, Nurcholis. 1995. Masyarakat Religius. Jakarta: Paramadina.

Sukandi dalam buku Nurcholis Majjid. 2003. Nurcholis Madjid: Jejak Pemikiran dari Pembaharu Sampai Guru Bangsa. Yogyakarta: Pustaka Pelajar.

Madjid, Nurcholish. 2008. Tradisi Islam Peran dan Fungsi dalam Pembangunan di Indonesia. Jakarta: Paramadina. 
Madjid, Nurcholish. 1995. Islam Agama Kemanusian: Membangun Tradisi dan Visi Baru Islam Indonesia. Jakarta: Paramadina. 